\title{
“One of Us": Orphaned Selves and Legitimacy in Australian Autobiography
}

JACK BOWERS

Australian National University

\author{
Orsino: And what's her history? \\ Viola: A blank, my lord. \\ -Shakespeare, Twelfth Night, Act II, Scene IV
}

Wen she is brought before the New South Wales Children's Court aged fif-
teen, Sharyn Killens has already spent seven years of her life in an orphanage. She is charged with being "uncontrollable," and her mother suggests to the court that "it would be better for everyone if she was placed in an institution until she is eighteen" (Killens 88). So it is, with her mother's blessing, that Sharyn is sent to the notorious Parramatta Girls' Home (in the western suburbs of Sydney) and from there to the even more notorious Hay Institution for Girls in Central New South Wales. But Sharyn's history is anything but a blank, and she recounts how she filled in those blanks in her autobiography, The Inconvenient Child. Born in 1948, Sharyn was the illegitimate daughter of a white Australian woman and a black American sailor, but it took until 1989, forty-one years later, that her mother revealed his name. In her ten years in three state-sanctioned institutions, Sharyn is physically and emotionally abused and humiliated; during a short period outside the institutions during her adolescence she suffers an episode of multiple rape. As a stripper, alcoholic, drug addict, and, in later life, a highly successful cabaret singer on ocean liners, Sharyn has only wanted two things in life: to be loved and accepted by her mother, Grace; and to know her father's identity. This paper examines "orphaned" selves, in which the autobiographer is both orphaned in the sense of not knowing one or both birth parents, and orphaned in the sense of being estranged from a fully formed and completed self.

Sharyn's narrative is about belonging; or, as one who feels estranged by the circumstances and consequences of her life, about the desire for belonging. According to social theorist Elspeth Probyn, "if you have to think about belonging, perhaps you are already outside" (8). That is, at one level, seeking belonging already positions the seeker on the "outside." This outside might be social, but it also reflects a self-identity in which one's connectedness with people, families, communities, and 
an almost infinite number of other possibilities for identity formation is forged. The rupture between the outside world and self-identity is, in part, what I mean by "orphaned selves." Of course, Sharyn is also orphaned in the sense that her biological parents take very little active part in her upbringing, but I am more interested in the desire for "completion"-that is, to inscribe oneself into a genealogical history-and the repercussions of orphanhood for self-identity. In addition to The Inconvenient Child (2009), I will also consider Robert Dessaix's A Mother's Disgrace (1994), Gordon Matthews's An Australian Son (1996), and Kate Shayler's The Long Way Home (1999) with its sequel A Tuesday Thing (2004).

\section{SeEking Completion}

Institutional dwellings such as foundling hospitals, poor houses, orphanages, and asylums have a long and infamous history. By the early twentieth century, in Australia as elsewhere, it was considered more beneficial for children to be "boarded out" rather than housed in asylums for the destitute; whereas this idea of boarding out had been based originally on teaching a child a usefulness (usually exploiting their labor), the notion of adoption for love took hold, becoming known as sentimental adoption (Forkert 25). For children born out of wedlock, their lives were begun filius nullius, literally "the children of no-one" (Marshall and McDonald 4). Adoption law was state-based, and it was not until the rise of feminism in the 1970s-and with legislation protecting the rights of unmarried women-that there was a significant shift toward women keeping their children. With this came the impetus for legislation to allow adoptees and birth parents to find one another, followed by legislation enabling rights of access-e.g., Victoria (1985), South Australia (1988), and New South Wales (1990) (Marshall and McDonald 43). This is the context in which Killens, Dessaix, and Matthews sought out their birth parents. Although Shayler and Killens were not formally adopted, their circumstances resemble those told by Dessaix and Matthews in that they mirror similar struggles with shame and legitimacy.

One of the discourses that prevailed until the seventies was the "constructivist capacities" of adoption: "in this view of adoption, true belonging is not dependent on blood connections but is forged through love and nurturance which can transcend the actual circumstances of blood, birth, race and colour" (Spark and Cuthbert 8-9). In direct opposition is another powerful discourse around blood ties in which "the seeker finds herself in finding family, blood ties prevail over complicated histories of separation and involvement in other families, and [. . .] the irrefutable 'truth' of kinship as biology is revealed" (Spark and Cuthbert 9-10). Matthews, Killens, and Dessaix are all seduced by the promise of establishing blood ties: in very different ways, each discovers that the "truth' of kinship" comes with 
an ambivalence they never foresaw. These narratives articulate the tension between the capacity for growth and the "'truth' of kinship," between escaping one's past and finding belonging in one's past, between the opportunities to experiment with new selves and the longing for completion.

Completion is obviously a loaded term, for it implies there is something missing. Nowadays, theorists take it for granted that, as Paul Eakin puts it, "all identity is relational" (How Our Lives 43). Indeed, each of the narratives discussed here reflects precisely that relationality, and the impetus for this article is to explore how each narrator inscribes his or her self contextually within relationships, and how the fracturing of those relationships is so deracinating for self-identity. For most of us, there is no relationship more fundamental to selfhood than our relationships with our parents: they frame our lives from birth, their genes are inscribed within us, their narrative is inextricably a part of our own narrative, and to decouple self-identity from how we relate to our parents requires a certain level of identity gymnastics. However, as Eakin also points out, "the myth of autonomy dies hard" (How Our Lives 43). In his discussion of relationality, Eakin discusses "the "face-off' between experiential accounts of the 'I,' on the one hand, and deconstructive analyses of the 'I' as illusion on the other" (4). This resonates with what I have to say about completion and its underpinnings: completion is experientially integral to the fabric of these narratives-it is part of the seduction of the "truth' of kinship"-even though autobiographical theory would eschew the epistemology that such a project entails. Despite this apparent disjunction, the desire for completion does not demonstrate an autonomous selfhood, only that gaps and elisions within our past make the narrative of our self-identity incomplete; or, as Toby Volkman suggests above, that the dichotomy of "complete" and "incomplete" is as much about a construction of community, family, and identity as it is anything intrinsic to an individual.

Of course, autonomy and completion are different, and, in linking the discourse of completion with a sense of belonging, there is the risk that I am conveying the idea that belonging is a ticket to acceptance, as if belonging is the means and acceptance the ends. For Sharyn Killens, the search for completion comprises both the need for her mother's love and acceptance, and the need to know her father's history, circumstances, and whereabouts. Living with her mother is impossible, it seems; so, after being cared for in privately arranged fostering, Sharyn is placed at the age of five in St. Martha's Orphanage in Sydney. Life is one of strict order and regimented control: when to eat, to sleep, to wash, to sit down, to pray, what chores to do, when to do them, how to do them; beatings, including having her head forced down the toilet by one of the nuns, are commonplace. Her mother-"she looked like a fairytale princess so I named her Princess Mummy"-visits intermittently, often accompanied by her latest boyfriend (17). 
A cornerstone of Sharyn's identity is shame, or, as Rosamund Dalziell puts it in her study of shame in autobiography, "original shame." Dalziell observes one of the elements of shame as "an emotional response to an awareness that one has fallen short of another's expectations or one's own" (233); for Sharyn, her perception from an early age is that she indeed has fallen a very long way short. It is constantly instilled into Sharyn that she is dirty, bad, and unworthy; so, proving her worth to Princess Mummy-in part the need for love but also to escape "Sister Lucifer" at the orphanage-is her primary motivation and also her salvation. After her daughter has spent nearly three years in the orphanage, Grace is pressured into having her home for Christmas, a home that Grace shares with her own mother, and a home Sharyn has never seen before: "Living with my mother was all I had ever wanted. [. . .] It was my fantasy, my dream and I desperately wanted Mummy and me to live in a sweet little house where she would love me; just the two of us. In reality I was an embarrassing and unwelcome presence in my grandmother's house" (48). Sharyn clings to this fantasy for decades. Each time her mother visits the orphanage, Sharyn asks about coming home. Eventually, when Sharyn does live with her mother, first in the grandmother's house and later with Grace and her new husband and baby boy, the schism in their relationship is not healed, but festers in acrimony.

Legitimacy is also at the heart of Sharyn's desire for completion. Grace met Thaddeus Killens (Sharyn's father) at the Booker T. Washington Club in the inner Sydney suburb of Surry Hills, a nightclub established especially for black American sailors by the American Red Cross. The White Australia Policy underpinned a series of racially based policies across Australia, and nightclubs were usually for whites only. The social strictures that were intended to maintain a moral underpinning to the society-underpinnings around alcohol, employment, race, and sex-were actually the cause of her mother's shame and Sharyn's incredibly difficult life. That Sharyn is bad and dirty is instilled into her by the nuns who are perceived by the little girl to articulate a moral position reflected by their Christian values and supported by the state and by Princess Mummy. She is reminded for much of her lifemostly negatively-of her color, and that her color represents something shameful, dirty, illegitimate, and, through seeing Australian Indigenous people and race riots from the US on television, always oppressed.

All Sharyn was told was that her father was an American sailor who had drowned at sea. Wanting and needing more, Sharyn pressed the issue with her mother on visiting days at the orphanage: "[W]ho was he? Where was he? What did he look like? But she would become irritated and snap at me. 'He is dead. There is nothing left to be said about that.' Then she'd change the subject" (61). This short dialogue is instructive on two counts. Firstly, not knowing about her father gnaws at Sharyn for decades. After her release from Parramatta Girls' Home and a short stint 
with her mother, Sharyn moves to Kings Cross at the age of seventeen. Sydney's Kings Cross in the 1970s was a heady, 24-hour precinct of dance clubs, brothels, drugs, and partying. Through various jobs and relationships, and having two sons along the way, Sharyn is constantly tormented by the need to solve the mystery of her father. When, in her forties, she finally does trace him, he is in fact dead, although he had died only when Sharyn was in her thirties; contact with him could have been made if not for her mother's recalcitrance. Secondly, her mother's refusal to tell Sharyn anything about her father's circumstances eventually fractures their relationship terminally. In many ways, their relationship is defined by the absent father: for Grace, the shame attached to their relationship and the pain at him not returning as he apparently promised is unremitting and inescapable; for Sharyn, her mother's refusal to allow her some connection with her father is a punishment meted out to the daughter in place of Sharyn's father. Not only does Sharyn suffer the torment of being unable to know her father, she bears the brunt of the shame felt by her mother.

For Sharyn, though, the burden of shame means that she cannot let go. Firstly, finding the answers to her paternal heritage are important to her as a woman of color. In this there are parallels with Gordon Matthews's An Australian Son and any number of Indigenous narratives: ${ }^{1}$ living black in a predominantly white society already casts Matthews and Killens with a social identity on the margins, and this is exacerbated by the second motivator for discovering kin-their illegitimacy. Toward the end of the narrative, Sharyn details the history of the Killens clan in the US, mapping their family tree and giving her an explicit link to the family's genealogy. Likewise, Robert Dessaix gives an account of the Dessaix heritage in France, Bernard Smith gives a comprehensive history of his lineage in The Boy Adeodatus, and Germaine Greer traces her father's family in Daddy We Hardly Knew You.

Dessaix's search for origins-in his case for his mother-is also a gnawing preoccupation that, he comes to realize, is intrinsically a part of his own sense of self. Dessaix, though, comes to this realization obliquely. His narrative is a story about stories: the stories about ourselves that we tell ourselves-stories, indeed, which make our selves. In April 1988, Dessaix had what he calls a "pivotal experience." A woman who is looking for Dessaix's office in the center of Sydney randomly asks a passerby for help (Dessaix is, at this time, something of a radio personality); the passerby explains that her name used to be Yvonne Dessaix, the name Dessaix knew to be his mother's. On finding the woman shortly after, he establishes that she is not his mother, but Dessaix's desperate need to find this woman (and there is a sense of desperation) is really driven by an experience that occurred to him four years earlier, when he was assaulted one night in Cairo: "It grew out of it because in my spiralling upwards that night I realized that in all the stories I'd told myself about my life up to 
then I'd always circled around the question of my mother. [. . . A After Cairo I wanted to fill in this shaft of silence running up through the centre of my life" (20).

Dessaix here makes the point of origins explicitly, the fundamental story of genesis. The need for completion, to "fill in this shaft" as Dessaix would have it, is indicative of the primacy of self-identity as a wholeness. Barbara Yngvesson, in her study of transnational adoption, suggests that adoptees often experience a strong desire to return to an imagined "before' [. . . where 'real' belongings can be found" (Belonging 8). This leads, she suggests, to the search for origins, a "pull back to an allegedly prior (natural) state of completion, even as such journeys complicate belongings, entangling us in relations that can never be complete" (8). Although none of the writers studied here are transnational adoptees, this precisely describes what motivates each: the sense in which there is a past-and, therefore, an identity-that has been erased by the severing act. For Dessaix and Matthews it is adoption, for Shayler it is the death of her mother, and for Killens it is the continuing absence of her father. The reality, as Yngvesson points out, is that recovering the relations with the past can never be complete, and Dessaix, in particular, is self-consciously aware that his quest for completion can only be provisional.

In the absence of those origins, the young Dessaix invents some. More than simply an invented family, Dessaix imagines a whole city filled with buildings and streets, railways with timetables, even a language: "it wasn't just a fantasy or a game I played there with myself; it was and still is a parallel world" (26). Through this imagining he becomes inspired to learn French, and also to learn Russian, a passion which led to him living for some years in the Soviet Union and teaching Russian in Australia and elsewhere in universities. With its policies, religion, history, culture, and language, this land is "a parallel world" motivated by Dessaix's need "to belong somewhere, to give myself a history I had some control over. I'd known ever since I could know anything that I didn't come from where I was" (33). The sense of order and control in all of this should not be underestimated, for it is this controlling and ordering that empowers Dessaix to put things to rights, to fill in the holes of the unknown, and gradually to become more aware of his desire for origins. Again, as Eakin would alert us, it is interesting to see the language of narrative here: a plot, not just to find his mother, but a plot to make a story to tell, to "give a shape" to that story and his experience. Over several years, he searches for and finds his mother. This is the beginning of a whole new story.

While Dessaix invents a country in which he can belong, Gordon Matthews situates himself within a national identity and, for a time, with Indigenous Australia. Gordon is raised in middle-class Melbourne by his two foster parents and with three other foster children: "The neighbourhood in which our parents chose to raise their family was uncompromisingly Anglo-Saxon, a place of clearly defined values 
which were staunchly adhered to by families who remained for decades. Untainted by discord, it was difficult to imagine anywhere more predictable, safe or secure" (16). However, it becomes clear very early in his life that Matthews is uncharacteristically dark-skinned, with thick, curly black hair. His grandfather affectionately refers to him as his "little abo" (29).

Like Killens, who lives with a past that is made silent, Gordon's color is never mentioned. "In our Anglocentric environment it would have been indiscreet and inappropriate for anyone to refer to or make an issue of my apparent difference. That would have been disruptive, unjustifiable, and provoked discomfort all round" (31). But his awareness of that color was "incandescent": "I confronted my difference every time I examined myself in a mirror or studied family photos" (31). It is not surprising, therefore, that Gordon comes to accept that he is Indigenous. (Importantly, he makes connections across the Indigenous community, which also accepts him as such.) When he goes to university, he is encouraged to accept a scholarship reserved for Aboriginal people. His identification has profound results personally: "For the first time I felt a completeness impossible to explain. Now I could actually say who and what I was. My ruptured identity had been restored" (75). However, having identified as Aboriginal, Gordon soon realizes that this is simply a beginning to a much more complicated road: What does it mean to be Aboriginal? On what basis will other Aborigines accept him? If being Aboriginal is about identity rather than skin color or some biological racial fraction, what is Aboriginal about him? After being questioned by an Aboriginal man, Gordon had further doubts: "For the first time I was beginning to wonder precisely how Aboriginal I was. [. . .] My situation was beginning to make me feel incredibly uncomfortable" (94).

Gordon becomes a successful diplomat with the Department of Foreign Affairs and enjoys several overseas postings and a promising career. With some help, he establishes that his biological parents married at some point and are living in the US with their two children. His mother is Colette, an Australian of Irish background, and his father is an academic at the University of Iowa. Vivian came from Sri Lanka to Australia in 1948 as part of the Colombo Plan to complete his veterinary studies, a year after the Immigration Restriction Act of 1901-effectively the legislative document of the White Australia Policy, which denied entry into Australia by anyone who was deemed "non-white"-was repealed. But completion, as Gordon is to discover, is really only ever an aspiration: reliving memories, telling stories of one's past, experiencing life as it goes on-not to mention upheavals like meeting one's biological parents for the first time-all entail the (re)constructive process of selfidentity; if it is not necessarily, to use Matthews's words, a shredding of self, it is certainly a process of creating anew. At one moment, after only a couple of hours of having met for the first time, Colette suggests to Gordon and Vivian, "Why don't 
you two guys give each other a hug? [. . .] You haven't had the chance yet" (149). It is a question that sums up the dilemma for all of them. The irresistible desire for origins drives Matthews on two fronts-his orphanhood and his color-but rather than any sense of completion, it opens a door on a new set of relationships that necessitates confronting years of shame, pain, and yearning-not just for Gordon, but also for his parents.

\section{The Legacies of ORPHANHOOD}

The implications of opening this door are, for both Matthews and his biological family, ambivalent at best, in ways that no one foresaw. Colette and Vivian's house is "quintessential middle America," the houses in the neighborhood the same as "every other house in the street, the obligatory basketball hoop hung over the garage door" and "perfectly manicured lawns, scarcely a blade of grass out of place. It looked almost painted" (151). In a pivotal moment in the narrative, Gordon sits down with Vivian and Colette in their lounge to explain his "Aboriginal" heritage, an issue of which they are entirely unaware. Explaining the personal and professional consequences of his racial identity and its importance in seeking out his biological parents is, in retrospect, "a terrible thing to do" (154). Colette quickly understands the implications of Gordon's explanation: "So that's why you looked for us. It had nothing to do with wanting to find your parents as such. [. . .] You were searching for your race" (156). When the full weight of Gordon's story-his pain, his identity conflicts, and his motivations-is felt by his parents, their joy of connecting with their first born is overcome by the reality of their shared history. Understanding that his search was primarily to discover his racial heritage rather than to find his parents for family reasons is something that Colette and Vivian find hurtful and confusing. Shame is everywhere: profound, ongoing, indelible. Gordon feels as if he has taken on an Indigenous identity to which he is not entitled and, in so doing, unwittingly duped the Indigenous community and his Indigenous friends for the last fifteen years of his life. He feels instinctively that his professional success is also bound up with his Indigenous identity, now unraveled. He feels ashamed that his search for his parents was motivated by his need to resolve his racial identity, and ashamed by the added pain he has given his parents. Culturally, personally, and professionally, his entire sense of self seems fraudulent.

Matthews's journey from Indigenous orphan to Iowa, rather than creating a beginning for re-connection, seems ultimately damaging for both Matthews and his biological family, and visits between them over several years only deepen the wounds: "I realised that my natural parents and I had fundamentally different perspectives in our 'rediscovery.' My need was to explain myself. By comparison, 
Colette and Vivian wanted to deal with what had occurred discreetly and in private. We were pulling in opposite directions" (222). For Colette and Vivian, acknowledging publically their new-found son meant coming to terms with the shame of their secret, both their illicit affair and the giving-up of their son for adoption; it also meant reconciling their past with their starkly different present. For Matthews, the unwillingness to acknowledge him publically continued the silence and shame around his origins, thereby also perpetuating the illegitimacy of his birth and his identity. Relations between them are severed for years. The final lines of the book concern their horror at Gordon's plans to write a book and, it seems, presage a complete breakdown in their relationship.

The legacy, then, for Matthews, is that the search for origins is filled with ambivalence and ends any hope of resolution. The irony, of which Matthews is not unaware, is that his fractured self-identity has been damaged even more, now with even less opportunity for completion. Where Killens is able to find a sense of belonging in her new family, Matthews finds estrangement; where Killens is able to write a new life narrative that brings together the disrupted and disparate narratives of her past, Matthews is left struggling to find a narrative for his future. Unlike Matthews, Killens found a family she so desperately sought. In contrast with Matthews, Killens does win out: she eventually finds out her father's name; she traces his records, ultimately being accepted into his warm, welcoming, and loving family. However, while her narrative is a story with a happy ending, it belies a life ruptured by a self-identity configured around shame and worthlessness.

The Killens family accepts Sharyn unconditionally. This certainly ameliorates some of the years of pain, and it also empowers her to confront some of that pain. In welcoming her into the family, a deep and abiding relationship is established, rewriting Sharyn's sense of belonging in the process, but this certainly does not resolve the past. Ironically, the times spent in St. Martha's, Parramatta Girls' Home, and Hay are deeply important in Killens's self-identity. In her exploration of place and belonging for ex-inmates of Parramatta Girls' Home, Corrinne Franklin suggests that "even 'bad' spaces can become meaningful places-places of value and importance to those whose identity they have shaped" (158). As Franklin notes, being one of the "Parra girls" is a badge of honor at some level, and surviving its deprivations no small achievement. Killens takes that legacy with her with a mixture of ambivalence, pride, and ongoing pain.

For both Killens and Matthews, the repercussions of their orphaned lives is really only one part of their narratives. For Kate Shayler, the consequences of her early life in an orphanage are drawn in detail, mapped across her personal and professional life over decades in sometimes harrowing detail. Shayler is not an orphan insofar as she knows her father, her one living parent, and sees him regularly; 
as she relates in The Long Way Home, the first four years of her life were "secure in [her] mother's love" (4). But her world fell apart with her mother's death in 1954, an event in itself that was incomprehensible to the little girl, and she was placed in the Burnside Presbyterian Homes for Children in Marrickville, Sydney. Reid Home was "one of Burnside's many castle-like buildings, huge, imposing and nothing like a family home. It was shiny, cold, hard and immaculately clean. There were no nursery rhymes on warm laps, no joyous laughter or noisy chaos" (9). There are the usual endless regulations, all enforced according to a strict, unbending chronological routine: hair is combed, nails are checked, heads are bowed in prayer, plates are cleared, teeth are cleaned, straight lines of children are made at each step along the way. The surveillance, punishment, and control leave the young Kate with a selfidentity based upon being dirty, being bad, and being worthless, and they leave her without anyone she can trust or anyone she can love; some small elements notwithstanding, life at Burnside seems determined to expunge these from the children's lives. However, in addition to an institution seemingly managed in order to prevent any sense of belonging, it is the "carers" who create the real damage.

According to the narrator, "the matrons looked after us in a tradition that was proudly Christian and whose purpose was, first and foremost, to save our souls" (9). From Reid to Ivanhoe, where she moves aged seven, Kate meets the wild, screeching, and indomitable Miss Yates. By way of introduction, Miss Yates blames Kate for a sexual abuse that Kate had suffered from one of the young boys: "So this is the dirty little thing I've heard about. [. . .] Don't you dare try any of your nonsense here or woe betide you" (40). The institution (here and in other narratives) creates for itself both the authority of decreeing what is normal (and aberrant) and the power to enforce its normative values and behaviors upon its inmates. It deliberately establishes a code whereby those who fail to meet those standards-that is, all the children of the orphanage-are ostracized, bullied, denigrated, and humiliated in the most personal of ways. Not surprisingly then, for a girl already lost without her mother and terrified by her sexually abusive father, the girl's trauma is manifest mentally, physically, and emotionally.

A Tuesday Thing maps the arc of Shayler's recuperation, of rewriting the narrative of self-identity anew, again and again, episode by episode, until it is something that she can take into the future. Despite wanting desperately to get married and have children, she remains unmarried and childless, but slowly she develops an independent life, finding some success as an early childhood teacher. Through gradually connecting with relatives, Kate realizes that her self-identity is still connected with her long dead mother and, further, that much of her sense of alienation is part of the loss of family. Kate learns that a number of her relatives were willing and able to provide a strong support base for the children as they were growing up, but could not 
look after all three. However, as Kate discovers in the file retrieved from Burnside many years later, her father wanted them to remain together so that he could maintain close contact with them as a family unit: if they had been placed separately with relatives across Sydney, his role in their lives risked being significantly diminished. Given Kate's account of life in the orphanage-even setting aside her father's abuse of his daughters-it is clear that they went to the orphanage largely to suit his needs rather than their interests. It also becomes clear that the relationships between the three children as adults are, at best, distant. Finding a network of caring relatives, then, is a bittersweet discovery, supporting and nurturing the adult Kate, but also reminding her that the legacy of a childhood in the orphanage-and possibly her father's abuse-could have been avoided. It is not surprising that the final chapters of A Tuesday Thing describe Kate's reconnection with her extended family, redrawing those familial relationships and, in so doing, helping to rewrite Shayler's self-identity; ironically though, the relationship she has with her predatory psychologist, Tony Benton, provides the impetus for her to overcome much of the legacy of her early life.

Shayler's determination to bring Tony Benton to account is a chance to enact the strength she has developed over two decades of healing. While the experiences of the orphanage and her father overwhelmed Shayler-and the manipulative psychologist nearly so-her career as a teacher, her university study, the support of friends and a nurturing psychologist (which Kate finds after her relationship with Benton) are all strands of her life that help Shayler to become assertive and resilient. Shayler alerts the Complaints Unit of the Department of Health and persists through a lengthy, bureaucratic, and emotionally draining process over four years to bring her complaint against Benton to a just conclusion. Like her father, Benton has institutional support and respect on his side, including a public façade of respectability with all its patriarchal assumptions. In many ways, Kate's outing of Benton's behavior is a rewriting of her silence around her father: the contexts and the behaviors are significantly different, but the parallels of love, dependence, and the abuse of power are unmistakable.

The process of remembering enables her more clearly to see the connections between the death of the mother, the abuse she suffered at the orphanage, and the abuse she suffered at the hands of her father. The losses-of her mother, of childhood play, of family relationships, of security-and the absences-of love and security-are identified as enduring strands that are woven indelibly into her adult life. Ultimately, the recognition of this legacy helps Shayler to reconfigure a self-identity in which she is not to blame, is not at fault, and can be self-empowered. It is fitting that A Tuesday Thing finishes with Kate meeting David, a former orphan from Burnside. Her embarking on what appears to be a fulfilling relationship completes an arc that really began in the opening scenes of The Long Way Home, when she is cast off into 
the loneliness of the orphanage. By the closing pages of A Tuesday Thing, the narrator has expurgated the outrages of her childhood and found a sense of belonging in which she is no longer overwhelmed by the abuse. That is, The Long Way Home and A Tuesday Thing are framed by the search for "completion" of a self-identity that she sees as having been taken away from her by the nuns and her father; in the epilogue she refers back to "the long way I took home to my wholeness" (Tuesday 509).

\section{Self-IDentity ANd Belonging}

What I have been teasing out here are the connections between self-identity and belonging. For these autobiographers, being orphaned in some sense has profoundly eroded that self-identity. The loss associated with the loss of family connection and connectedness has instilled a perception of being without something or having missed out on something. This loss is filled with ambiguities of belonging: belonging is inseparable from loss insofar as while one has a history, there is an understanding that one's history has been erased and replaced with another history; one belongs insofar as this is the culture I know, there is no culture competing for recognition within me; but I don't belong because my history is largely unknown, silenced, foreshortened, or fabricated; I don't belong because those around me see me as not belonging, that my difference inevitably and always sets me apart; even the family to whom I belong are different from me-we are not one; attached in some way, but not as one. Belonging, it seems to me, is seen most clearly when one understands what it is to be estranged.

The completion promised by a family connectedness, even if such a connectedness has been achieved, has not overcome the erosion of self-identity of the past. What Elizabeth Honig observes about transnational adoptees is true of these autobiographers, that they "live with phantom lives, lives defined as possible but unlived" (215). This may also be said for Killens, whose discovery of her father's family enables her to imagine the life she may have led with him in a black community; less attractive but nevertheless phantom, Matthews meets the family that, with ever so slight a change in fate, might have been his own life; and Shayler often imagines what it might have been like if her mother hadn't died, if she hadn't been brought up in an orphanage, and if she had not suffered her father's abuse. With the possible exception of Dessaix's narrative, the legacy of loss has been profound: these narratives are anguished and reading them is often a disturbing experience; even Dessaix, whose self-conscious narrative enjoys dabbling with various identity tropes even as he undercuts them, cannot escape the realization that the discovery of his mother only brings new contingencies for self-identity. Ultimately, self-identity is always a process of establishing some sense of belonging, or at least recognizing one's estrangement. 


\section{Note}

Given the history of removal of Indigenous Australian children from their parents, establishing lineage has been an ongoing issue for countless Indigenous people in Australia; indeed, an organization, Link-Up, was established for this purpose, originally in NSW in 1980 (http://www.linkupnsw.org.au/). Scores of narratives by Indigenous Australians seeking their heritage have now been published, and they deserve a separate study.

\section{Works Cited}

Dalziell, Rosamund. Shameful Autobiographies: Shame in Contemporary Australian Autobiographies and Culture. Melbourne: Melbourne UP, 1999. Print.

Dessaix, Robert. A Mother's Disgrace. Sydney: Angus and Robertson, 1994. Print.

Eakin, Paul John. How Our Lives Become Stories. Ithaca: Cornell UP, 1999. Print.

Franklin, Corrinne. "Belonging to Bad: Ambiguity, Parramatta Girls and the Parramatta Girls Home." Geographical Research 52.2 (2014): 157-67. Wiley Online Library. Web. 24 April 2014.

Forkert, Joshua. "'Lacerated Feelings and Heart-Burnings': A Background to Adoption in Australia." Other People's Children: Adoption in Australia. Eds. Ceridwen Spark and Denise Cuthbert. Melbourne: Australian Scholarly Publishing, 2009. 23-36. Print.

Greer, Germaine. Daddy We Hardly Knew You. London: Hamish Hamilton, 1989. Print.

Honig, Elizabeth Alice. "Phantom Lives, Narratives of Possibility." Cultures of Transnational Adoption. Ed.

Toby Alice Volkman. Durham and London: Duke UP, 2005. 213-22. Print.

Killens, Sharyn, and Lindsay Lewis. The Inconvenient Child. Sydney: Miracle Publishing, 2009. Print.

Marshall, Audrey, and Margaret McDonald. The Many-Sided Triangle: Adoption in Australia. Melbourne: Melbourne UP. 2001. Print.

Matthews, Gordon. An Australian Son. Melbourne: William Heinemann, 1996. Print.

Murphy, Kate, Marian Quartly, and Denise Cuthbert. "'In the Best Interests of the Child': Mapping the (Re)emergence of Pro-adoption Politics in Contemporary Australia." Australian Journal of Politics and History 55.2 (2009): 201-18.

Novy, Marianne, ed. Imagining Adoption: Essays on Literature and Culture. Ann Arbor: U of Michigan P, 2001. Ebrary Academic Complete International Subscription. Web. 22 August 2014.

Probyn, Elspeth. Outside Belongings. New York: Routledge, 1996. Print.

Shayler, Kate. The Long Way Home. Sydney: Random House, 1999. Print.

—. A Tuesday Thing. Sydney: Random House, 2004. Print.

Smith, Bernard. The Boy Adeodatus: The Portrait of a Lucky Young Bastard. Melbourne: Allen Lane, 1984. Print. Spark, Ceridwen, and Denise Cuthbert, eds. Other People's Children: Adoption in Australia. Melbourne: Australian Scholarly Publishing, 2009. Print.

Yngvesson, Barbara. "'Going Home': Adoption, Loss of Bearings and the Mythology of Roots.” Cultures of Transnational Adoption. Ed. Toby Alice Volkman. Durham and London: Duke UP, 2005. 25-48. Print. Belonging in an Adopted World: Race, Identity, and Transnational Adoption. Chicago: U of Chicago P, 2010. Print. 


\section{CONTRIBUtors}

Chris Andrews teaches at Western Sydney University. He has published two books of poems: Cut Lunch (Indigo, 2002) and Lime Green Chair (Waywiser, 2012). He has also translated books of fiction by Latin American writers, including Roberto Bolaño's By Night in Chile (Harvill, 2003) and César Aira's The Musical Brain and Other Stories (New Directions, 2015).

Liz Argall has published work in Meanjin, The Pedestal Magazine, and Strange Horizons. Two of her short stories have become plays that are regularly performed, and audio versions of her stories can be found in Pseudopod, Podcastle, and EscapePod. An Australian living in Seattle, she creates the webcomic Things Without Arms and Without Legs and plays roller derby with the Rat City Rollergirls. Her website is http://lizargall.com/

John Beston was born in rural NSW and took his PhD at Harvard University. He has divided his life between America and Australia and academic interests between Old French and Australian Literature. Retired to Coffs Harbour, NSW, he is affiliated with the School of Languages at the University of Queensland.

Judith Beveridge is the author of six collections of poetry, most recently Devadatta's Poems and Hook and Eye: a selection of poems published by George Braziller in 2014 for the US market. She is the poetry editor for Meanjin and teaches poetry writing at postgraduate level at the University of Sydney. Her poems have been widely anthologized, studied, and translated. This is her first appearance in Antipodes.

Greg Bogaerts is a writer living in Newcastle. His novels include Black Diamonds and Dust.

Jack Bowers teaches in the College of Asia and the Pacific at the Australian National University. His book on belonging, Strangers at Home (Cambria Press), is due for release in 2016.

Marita Bullock currently teaches Australian literature in the Department of English at The University of Sydney. Her research investigates the intersection of historiography and fiction in literature, film, and visual culture. She is the author of Memory Fragments: Visualising Difference in Australian History.

Alison Burns teaches in the School of Communication \& Creative Arts at Deakin University in Melbourne, Australia. Her specialist academic background is in professional writing and linguistics. She has taught professional writing, language acquisition, and literacy at under- and post-graduate levels. Her research is focused on writing processes and pedagogy.

David Carter FAHA is Professor of Australian Literature and Cultural History the University of Queensland and Manager, Australian Studies in China Program (AustraliaChina Council). He is currently editing the online Oxford Research Encyclopedia of Australian Literature. He has published widely on Australian literature and publishing history.

Danica Čerče is an Associate Professor of Literatures in English, teaching at the Faculty of Economics, University of Ljubljana. Her field of research includes American and Australian literature, and Translation Studies. She is the author of two books, several book chapters, and articles published in various academic journals. She is on the editorial board of Coolabah and Steinbeck Review, and a Vice President of the International Society of Steinbeck Scholars. 
Reproduced with permission of the copyright owner. Further reproduction prohibited without permission. 